\title{
Feeding sorghum stover to Ethiopian goats and sheep: effect of amount offered on intake, selection and performance
}

\author{
A. A. O. Aboud', E. Owen'ㄹ, J. D. Reed ${ }^{3}$, A. N. Said' ${ }^{1}$ and A. B. McAllan ${ }^{4}$ \\ 'International Livestock Centre for Africa, PO Box 5689, Addis Ababa, Ethiopia \\ ${ }^{2}$ University of Reading, Department of Agriculture, 1 Earley Gate, PO Box 236, Reading RG6 2AT \\ ${ }^{3}$ University of Wisconsin-Madison, Department of Meat and Animal Science, 53706-1284, USA \\ ${ }^{4}$ AFRC Institute of Grassland and Environmental Research, Hurley, Maidenhead SL6 5LR
}

\section{Introduction}

Aboud, Owen, Reid and McAllan (1990) found that intake and selection of sorghum stover by sheep increased as the ad libitum amounts offered $(\mathrm{g} / \mathrm{kg}$ mass per day) were increased from 25 to 50 and 75 . The greater intakes resulted in improved growth rates. In view of the importance of goats in smallholder tropical-agriculture and the fact that goats are considered selective feeders, the present trial compared the response of goats and sheep when offered increasing ad libitum quantities of sorghum stover.

\section{Material and methods}

Sorghum (bird-resistant Seredo) was grown at Melkassa in the Rift Valley. Fourteen days after handharvesting grain in November 1988, stover was hand-cut and transported to the International Livestock Centre for Africa at Debre Zeit. The stover was chopped (tractor-mounted Alvan Blanch Chaff Cutter) and stored for 1 month before feeding.
Twenty-four Galla bucks (ca. 12 months old) and 24 Ethiopian Lowland rams ( $\mathrm{ca} .15$ months old) were used in a $2 \times 3$ factorial experiment with eight replicates. Animals were individually penned and given $155 \mathrm{~g} /$ day of cottonseed cake and offered one of three ad libitum amounts of stover $(25,50$ or $75 \mathrm{~g} / \mathrm{kg}$ mass per day). Salt lick and water were provided. Following a preliminary period of 21 days, the experiment lasted 75 days. Amounts of stover offered and refused were recorded daily; samples were fractionated into leaf, leaf sheath and stem to assess selection.

\section{Results}

For intake and growth rate, there were no significant interactions between species and amount of stover offered $(P>0.05)$. Main effect means are shown in Tables 1 and 2. Ram growth rates were more than twice those of bucks; mature weight differences (sheep 27 to $32 \mathrm{~kg}$; goats 18 to $26 \mathrm{~kg}$ ) would contribute to this.

Table 1 Main effect means for species

\begin{tabular}{|c|c|c|c|c|}
\hline & \multicolumn{2}{|c|}{ Species } & \multirow[b]{2}{*}{ s.e. } & \multirow{2}{*}{$\begin{array}{l}\text { Significance } \\
\text { of speciest }\end{array}$} \\
\hline & Goats & Sheep & & \\
\hline No. of animals & 21 & 23 & & \\
\hline Initial weight (kg) & $14 \cdot 5$ & $17 \cdot 0$ & & \\
\hline Growth rate (g/day) & 21.5 & 48.2 & 3.74 & $* *$ \\
\hline Stover offered (g DM per day) & 731 & 752 & & \\
\hline \multicolumn{5}{|l|}{ Stover refused (g DM per kg } \\
\hline DM offered) & 369 & 272 & $8 \cdot 3$ & $* * *$ \\
\hline Stover intake ( $\mathrm{g}$ DM per day) & 428 & 475 & 11.1 & $* * *$ \\
\hline
\end{tabular}

+ There were no significant species $X$ amount interactions $(P>0.05)$. 
Table 2 Main effect ineans for amount of stover offered

\begin{tabular}{|c|c|c|c|c|c|}
\hline & \multicolumn{4}{|c|}{$\begin{array}{l}\text { Amount offered } \\
\text { (g stover per kg mass per day) }\end{array}$} & \multirow[b]{2}{*}{ Significancet } \\
\hline & 25 & 50 & 75 & s.e. & \\
\hline No. of animals & 15 & 15 & 14 & & \\
\hline Growth rate (g/day) & 19.5 & 39.8 & 47.9 & 4.58 & $* * *$ \\
\hline Stover offered (g DM per day) & 352 & 757 & 1143 & & \\
\hline \\
\hline kg DM offered) & 103 & 356 & 509 & 10.2 & $* * *$ \\
\hline Stover intake (g DM per day) & 315 & 487 & 563 & 13.7 & $* * *$ \\
\hline
\end{tabular}

+ There were no significant species $X$ amount interactions $(P>0.05)$.

Both species responded similarly (cf. absence of interaction) in that intake and growth rate increased with increasing amounts of stover offered (Table 2). The largest response occurred to increasing the amount of stover from 25 to $50 \mathrm{~g} / \mathrm{kg}$ mass per day.

The composition $(\mathrm{g} / \mathrm{kg})$ of the stover offered was: leaf, 84; leaf sheath, 237; stem, 616. Mean leaf content $(\mathrm{g} / \mathrm{kg})$ of refusals from the 25,50 and 75 offer-rates were: goats, 1, 2, 5; sheep, $0.1,0.5,12$. Leaf-sheath contents $(\mathrm{g} / \mathrm{kg})$ of refusals were: goats, 40, 67, 113; sheep, 29,60, 145. Both goats and sheep selected for leaf and leaf sheath.

\section{Conclusions}

The data indicate that both goats and sheep are capable of selective feeding leading to increased intake and growth when they are offered increasing ad libitum amounts of chopped sorghum stover. For the genotypes used, growth rate of rams was more than double that of bucks. The generous feeding strategy used offers a method of alleviating the low nutritive value of sorghum stover as a dry-season food for small ruminants.

\section{Acknowledgements}

The work formed part of a project funded by ILCA and ODA. The first-named author was supported by NORAD.

\section{Reference}

Aboud, A. A. O., Owen, E., Reed, J. D. and McAllan, A. B. 1990. Feeding sorghum stover to Ethiopian sheep: effect of stover variety and amount offered on growth, intake and selection. Animal Production 50: 593 (abstr.). 